\title{
Description of Tropheryma whipplei gen. nov., sp. nov., the Whipple's disease bacillus
}

1 Unite des Rickettsies, Universite de la Méditerranée, Faculté de Médecine, CNRS UPRESA 6020, 27 Boulevard Jean Moulin, 13385 Marseille, France

2 Department of Medical Microbiology, University of Zürich, Gloriastrasse 30, 8028 Zürich, Switzerland

\author{
Bernard La Scola, ${ }^{1}$ Florence Fenollar, ${ }^{1}$ Pierre-Edouard Fournier, ${ }^{1}$ \\ Martin Altwegg, ${ }^{2}$ Marie-Noëlle Mallet ${ }^{1}$ and Didier Raoult ${ }^{1}$
}

Author for correspondence: Didier Raoult. Tel: +334913243 75. Fax: +334913877 72 e-mail: Didier.Raoult@medecine.univ-mrs.fr

\begin{abstract}
A detailed characterization was performed of the Whipple's disease bacillus, strain Twist-Marseille ${ }^{\top}$, isolated from the cardiac valve of a patient with Whipple's disease bacillus endocarditis. This strain was isolated and maintained on human embryonic lung fibroblast monolayers, but could not be cultivated in the absence of living eukaryotic cells. Two morphological forms were observed, with differing staining properties; an intracellular form with intact and degenerating bacteria within vacuoles of infected cells and an extracellular form with masses of bacteria embedded in an extracellular matrix. Determination of the DNA G+C content confirmed that it belongs to the high-G+C Gram-positive bacteria. Strain Twist-Marseille' (= CNCM I-2202') is proposed as the type strain of a new species within a new genus, Tropheryma whipplei gen. nov., sp. nov., that was provisionally created solely on the basis of 16S rRNA gene sequence data.
\end{abstract}

Keywords: Tropheryma whipplei, Whipple's disease, 'Tropheryma whippelii', cell culture, molecular characterization

\section{INTRODUCTION}

Whipple's disease is a systemic bacterial infection characterized by fever, weight loss, diarrhoea, lymphadenopathy and polyarthritis. Occasionally, it is also associated with cardiac manifestations such as myocarditis, pericarditis and endocarditis (Vital-Durand et al., 1997; Ratliff et al., 1984) or central nervous system involvement, including dementia, lethargy and neurological deficits (Maizel et al., 1970). The disease was first described by Whipple (1907) and its bacterial aetiology was confirmed in 1961 by electron microscopy (Yardley \& Hendrix, 1961). Diagnosis of infection is usually based on histopathological examination of a duodenal biopsy showing infiltration by large macrophages that contain periodic acid-Schiff (PAS)-positive material (Black-Schaffer, 1949) or bacteria with a typical trilamellar membrane using electron microscopy. Wilson et al. (1991) and then Relman

\footnotetext{
Abbreviations: HEL, human embryonic lung; ITS, internal transcribed spacer; PAS, periodic acid-Schiff.

The GenBank accession numbers for the 165 rDNA, ITS and 235 rDNA domain III sequences of strain Twist-Marseille ${ }^{\top}$ are AF251035, AF248312 and AF248313, respectively.
}

et al. (1992) used broad-range primers to amplify bacterial 16S rRNA genes directly from infected tissue and then determined and compared the sequence to demonstrate that this bacterium belongs to the class Actinomycetes. On this basis, the bacterium was tentatively proposed as 'Tropheryma whippelii' (Relman et al., 1992). Determination of the nucleotide sequence of the 16S rRNA gene of ' $T$. whippelii' provided the basis for the development of speciesspecific diagnostic PCR systems (Ramzan et al., 1997). These PCR-based methods have become the standard diagnostic method for Whipple's disease. Recent PCR studies have demonstrated that ' $T$. whippelii' is probably a ubiquitous or commensal micro-organism (Street et al., 1999; Ehrbar et al., 1999; Dutly et al., 2000). 'T. whippelii' has remained uncultivable, despite much effort (Relman, 1997), and its characteristics have remained enigmatic. The report of the isolation of the Whipple's disease bacterium in 1997 using human macrophages inactivated with interleukin-4 (Schoedon et al., 1997) stimulated renewed interest in culture of the micro-organism, but this isolate could unfortunately not be subcultured. Using a shell-vial cell culture system, we recently isolated the Whipple's disease bacterium from the cardiac valve of a patient with Whipple's disease-related endocarditis and subse- 
quently established this strain in stable culture (Raoult et al., 2000a). The strain has been deposited at the Collection Nationale de Culture de Micro-organismes de l'Institut Pasteur, Paris, France, as strain Twist-

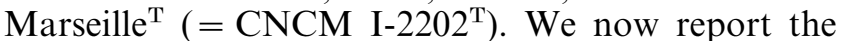
extensive characterization of this bacterium and formally propose to name this micro-organism Tropheryma whipplei gen. nov., sp. nov.

\section{METHODS}

Strain cultivation. Details of the isolation of ' $T$. whippelii' strain Twist-Marseille ${ }^{\mathrm{T}}$ have been described elsewhere (Raoult et al., 2000a). The strain was routinely subcultured in $150 \mathrm{~cm}^{2}$ cell culture flasks on human embryonic lung (HEL) cell monolayers (CCL-137; ATCC, Manassas, VA, USA) grown in $30 \mathrm{ml}$ minimal essential medium (Gibco) with $10 \%$ foetal calf serum (Gibco) and $2 \mathrm{mM}$ L-glutamine (Gibco) and incubated at $37^{\circ} \mathrm{C}$ in a $5 \% \mathrm{CO}_{2}$ atmosphere. Every 3-4 weeks (according to the infected cell ratio), supernatant from each of the infected cell culture flasks was removed and frozen at $-80^{\circ} \mathrm{C}$ for further studies. Infected cells were harvested by trypsinization and inoculated into three $150 \mathrm{~cm}^{2}$ cell culture flasks with fresh medium.

Subculture assays. Propagation was attempted in the mammalian cell lines CACO-2 (HTB-37; ATCC), HL-60 (CCL240; ATCC), MDCK (CCL-34; ATCC) and MRC-5 (CCL171; ATCC) and on solid or in liquid axenic media, chocolate agar (bioMérieux), Columbia sheep blood agar (bioMérieux), BCYE agar (bioMérieux), Coletsos (Sanofi Pasteur), Middlebrook and Cohn 7H10 (Becton Dickinson), Schaedler (bioMérieux) and brain-heart infusion broth (Sanofi Pasteur), incubated at 32 and $37^{\circ} \mathrm{C}$, under $5 \% \mathrm{CO}_{2}$, microaerophilic and anaerobic atmospheres. Culture was also attempted in the cell culture medium alone and cell culture medium with lysate of HEL cells incubated at 32 and $37^{\circ} \mathrm{C}$ in a $5 \% \mathrm{CO}_{2}$ atmosphere.

Production of mouse polyclonal antibodies. Six- to eightweek-old immunocompetent BALB/c mice were inoculated subcutaneously with $0.5 \mathrm{ml}$ of a suspension of $10^{6}$ bacterial cells $\mathrm{ml}^{-1}$ obtained from the supernatant of infected cells and Freund's complete adjuvant. Inoculations were repeated on days 10, 20 and 30. In order to check whether the bacteria were immunogenic to mice, $500 \mu$ blood was sampled by puncture of the retro-orbital sinus on day 19. After centrifugation, antibody titres were estimated with anti-mouse globulin-fluorescein conjugate (Immunotech). On day 40, the mice were sacrificed and blood was sampled by intracardiac puncture. Before use, sera were adsorbed with HEL cells in order to remove non-specific anti-cell antibodies. Sera were mixed with a pellet of washed HEL cells. Cells were suspended in the serum and the mixture was shaken overnight at room temperature. After centrifugation at $10000 \mathrm{~g}$ for $10 \mathrm{~min}$, the supernatant was removed and frozen at $-80{ }^{\circ} \mathrm{C}$ for further studies.

Staining for optical microscopy. Harvested infected cells and supernatant were cytocentrifuged separately for staining. Slides were stained by acridine orange, Gram, Ziehl, Gimenez, May-Grünwald Giemsa and PAS (Chapin, 1995; Gimenez, 1964; Woods \& Walker, 1996).

Immunofluorescence staining. Cells and supernatant were cytocentrifuged separately and fixed for $10 \mathrm{~min}$ in methanol. Immunofluorescence detection was also carried out on infected cells cultured in shell vials (Raoult et al., 2000a). Four weeks after inoculation, monolayers in shell vials were fixed for $10 \mathrm{~min}$ in methanol and washed twice with PBS. One-hundred microlitres of the primary antibody (patient serum or mouse polyclonal antibody), diluted 1:200 in PBS with $3 \%(\mathrm{w} / \mathrm{v})$ non-fat dried milk, was added to the slides and incubated in a moist chamber at $37^{\circ} \mathrm{C}$ for $30 \mathrm{~min}$. After three washes in PBS, the slides were incubated for $30 \mathrm{~min}$ at $37^{\circ} \mathrm{C}$ with $100 \mu$ fluorescein isothiocyanate-conjugated goat anti-human or anti-mouse Ig (bioMérieux) diluted 1:200 in PBS containing $0.2 \%$ Evans blue. After three washes with PBS, the cover slips were mounted (cells face down) in phosphate-buffered glycerol medium pH 8 (Sanofi Pasteur) and examined using an epifluorescence microscope at $400 \times$ magnification.

Electron microscopy. Harvested infected cells and supernatant were suspended separately for fixation in $2.5 \%$ glutaraldehyde in $0 \cdot 1 \mathrm{M}$ cacodylate buffer $(\mathrm{pH} 7 \cdot 2)$ containing $0.1 \mathrm{M}$ sucrose for $1 \mathrm{~h}$ at $4{ }^{\circ} \mathrm{C}$. Fixed cells were washed overnight with the same buffer and then fixed for $1 \mathrm{~h}$ at room temperature with $1 \%$ osmium tetroxide in $0 \cdot 1 \mathrm{M}$ cacodylate buffer. Dehydration was performed through washes of increasing concentrations $(25-100 \%)$ of acetone. The cells were then embedded in Araldite (Fluka). Thin sections were cut from embedded blocks using an Ultracut microtome (Reichert-Leica) and were post-stained with a saturated solution of methanol/uranyl acetate and lead nitrate with sodium citrate in water before examination using a JEOL 1220 electron microscope The presence of flagella was assessed by depositing supernatant on copper grids coated with Formvar (Sigma) and staining with a $0 \cdot 33 \%$ solution of uranyl acetate.

Purification of bacteria for SDS-PAGE and $\mathbf{G}+\mathbf{C}$ content analysis. HEL cells infected with bacteria were harvested from forty $150 \mathrm{ml}$ flasks into $40 \mathrm{ml}$ PBS. Trypsin (Gibco) was added to the suspension to a final concentration of $5 \mathrm{mg}$ $\mathrm{ml}^{-1}$ and the suspension was incubated at $30^{\circ} \mathrm{C}$ for $45 \mathrm{~min}$. Next, the suspension was subjected to sonication (three periods of $1 \mathrm{~min}$ on ice), following which unlysed cells were removed by centrifugation at $100 \mathrm{~g}$ for $15 \mathrm{~min}$. The supernatant was layered onto a $25 \%(\mathrm{w} / \mathrm{v})$ sucrose solution in PBS. After centrifugation at $9000 \mathrm{~g}$ for $30 \mathrm{~min}$ at $4{ }^{\circ} \mathrm{C}$, the pellet containing bacteria was resuspended in $2 \mathrm{ml} \mathrm{PBS}$ and layered carefully onto a 25:45\% (w/v in PBS) renograffin step gradient. This gradient was subjected to centrifugation at $130000 \mathrm{~g}$ for $1 \mathrm{~h}$ at $5^{\circ} \mathrm{C}$. The bacteria were then harvested from the 25:45\% interface and washed twice in PBS. For SDS-PAGE, bacteria were resuspended in sterile distilled water at a final concentration of $1 \mathrm{mg} \mathrm{ml}^{-1}$. For DNA G $+C$ content analysis, bacteria were resuspended in $2 \mathrm{ml} \mathrm{PBS}$ and proteinase $\mathrm{K}$ was added to a final concentration of $10 \mathrm{mg}$ $\mathrm{ml}^{-1}$. This suspension was incubated overnight at $37^{\circ} \mathrm{C}$ and then submitted to a further centrifugation on a $25: 45 \%$ renograffin step gradient. The bacteria were harvested and washed as described above and then resuspended in the smallest possible volume of sterile distilled water before use.

SDS-PAGE and Western blotting. In order to characterize the total protein profile of strain Twist-Marseille ${ }^{\mathrm{T}}$, samples were sonicated (three periods of $1 \mathrm{~min}$ on ice) and the proteins were then extracted in SDS-PAGE sample buffer [buffer 1 containing $200 \mathrm{mM}$ Tris $/ \mathrm{HCl}, \mathrm{pH} 8.8,5 \mathrm{mM}$ EDTA, $1 \mathrm{M}$ sucrose and $0.01 \%$ bromophenol blue; buffer 2 containing $18 \%$ SDS, $0.3 \mathrm{M}$ dithio-1,4-erythritol and 5\% (v/v) 2mercaptoethanol; the sample buffer corresponds to 1 vol. buffer 2 to 4 vols buffer 1] and heated, for $15 \mathrm{~min}$ at $100^{\circ} \mathrm{C}$. 

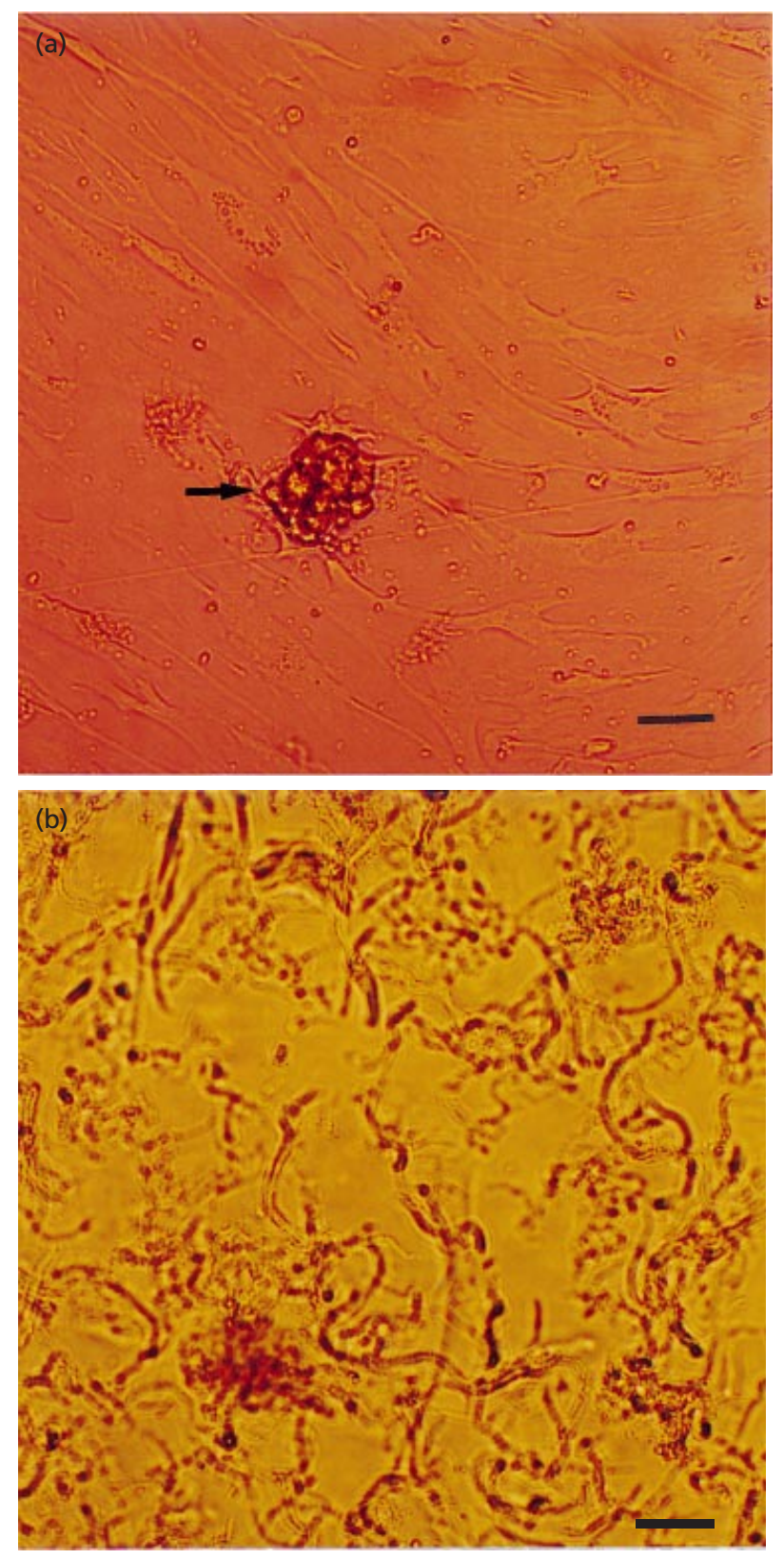

Fig. 1. Cultivated cells of $T$. whipplei observed using an inverted microscope on a 6-week-old culture. Bars, $30 \mu \mathrm{m}$. (a) Large, coarse, rounded structures observed on cell monolayers (arrow). (b) Long, rope-like structures due to aggregated extracellular bacteria.

SDS-PAGE was performed by the method of Laemmli (1970) on $9-16 \%$ polyacrylamide linear gradient gels $(18 \mathrm{~cm} \times 20 \mathrm{~cm} \times 1.5 \mathrm{~mm})$ at $60 \mathrm{~mA}$ constant current per gel and $10{ }^{\circ} \mathrm{C}$, until the dye front reached the bottom of the gel. Proteins were visualized with silver stain according to the modified Blum procedure (Nesterenko et al., 1994).

For Western blotting, proteins were extracted and heated as in SDS-PAGE prior to electrophoresis on $8 \%$ separating gels. A total of $10 \mu \mathrm{g}$ total protein was loaded per lane. Following electrophoresis, the proteins were electroblotted to nitrocellulose membranes at $100 \mathrm{~V}$ for $1 \mathrm{~h}$ at $10{ }^{\circ} \mathrm{C}$. The membranes were blocked with $5 \%(\mathrm{w} / \mathrm{v})$ non-fat dried milk in Tris buffer $(10 \mathrm{mM}$ Tris $/ \mathrm{HCl}, \mathrm{pH} 8.8,150 \mathrm{mM} \mathrm{NaCl}$, $0.1 \%$ Tween 20 ) overnight and then incubated with mouse antiserum against strain Twist-Marseille ${ }^{\mathrm{T}}$ diluted 1:2000 in $3 \%(\mathrm{w} / \mathrm{v})$ non-fat dried milk in PBS for $1 \mathrm{~h}$ at room temperature. After three 10 min washing steps in Tris buffer, the membranes were incubated with goat anti-mouse Ig $\mathrm{G}+\mathrm{M}$ (Jackson ImmunoResearch) diluted to 1:3000 with PBS. After three washes in Tris buffer, immunodetection was performed by using the ECL chemiluminescence system (Amersham) followed by exposure to Boehringer Mannheim film for $15 \mathrm{~s}$.

PCR amplification and sequencing of the 16S rRNA gene, internal transcribed spacer (ITS) region and domain III of the 235 rRNA gene. For the study of extracellular bacteria, $500 \mu \mathrm{l}$ cell culture supernatant was centrifuged at $1000 \mathrm{~g}$ for $10 \mathrm{~min}$ in order to remove cells. The supernatant was then centrifuged at $12000 \mathrm{~g}$ for a further $5 \mathrm{~min}$. The pellet was resuspended in $90 \mu \mathrm{T} \mathrm{TE}$ buffer. For the study of intracellular bacteria, cells from an infected cell culture flask were harvested in $500 \mu \mathrm{l}$ culture medium. Cells were rinsed three times in PBS by centrifugation at $1000 \mathrm{~g}$ for $10 \mathrm{~min}$. The resulting pellet was resuspended in $90 \mu \mathrm{T}$ TE buffer. Suspensions of intracellular and extracellular bacteria were frozen separately in liquid nitrogen and thawed immediately at $100{ }^{\circ} \mathrm{C}$ in a heat block. This procedure was repeated three times. Ten $\mu \mathrm{l}$ of a stock solution of $10 \mathrm{~g}$ lysozyme $1^{-1}$ (Research Organics) was added and the tubes were incubated at $37^{\circ} \mathrm{C}$ for $1 \mathrm{~h}$. DNA was extracted using Qiagen columns (QIAamp tissue kit; Qiagen) as described by the manufacturer. Using the broad-range primer pair fD1 and rP2 (Weisburg et al., 1991), the 16S rRNA gene was amplified by PCR. This fragment was sequenced as described previously (La Scola et al., 1998). The 16S-23S rDNA ITS was amplified and sequenced by using the primers tws $3 / \mathrm{f}\left(5^{\prime}\right.$ CCGGTGACTTAACCTTTTTGGAGA-3') and tws4/r (5'-TCCCGAGGCTTATCGCAGATTG-3') as described previously (La Scola et al., 1997; Hinrikson et al., 1999). A fragment of domain III of the $23 \mathrm{~S}$ rDNA was amplified and sequenced using the primers TW-23InsF (5'-GGTTGATATTCCCGTACCGGCAAAG-3') and TW-23InsR2 (5'GCATAGGATCACCAATTTCGCGCC-3') as described previously (Hinrikson et al., 2000a). A commercially available sequencing kit was used for sequencing (dRhodamine Terminator cycle-sequencing ready reaction kit with AmpliTaq Polymerase FS; PE Applied Biosystems). Sequencing products were purified by ethanol/magnesium precipitation and then resolved on a $5 \%$ polyacrylamide gel (Long Ranger Singel packs, type 377-36cm WTR; Tebu) by electrophoresis on an ABI PRISM 377 DNA sequencer (Perkin Elmer).

Analysis of sequence data. Sequences of the 16S rRNA gene, ITS and domain III of $23 \mathrm{~S}$ rRNA gene of strain TwistMarseille $^{\mathrm{T}}$ were compared with DNA sequence databases using the program BLAST 2.0 (NCBI).

DNA G + C content analysis. DNA was extracted as described previously (Ausubel et al., 1995). Nucleosides residue analysis was performed by HPLC using a model L6200A system pump and a UV detector L4250 (Merck Clevenot). An aliquot of $5 \mu 1$ of the sample was applied onto a Nucleosil 100-SC18 Lichrocart column $(4 \times 250 \mathrm{~mm})$ (Merck). Elution was carried out at room temperature using a mixture of $0 \cdot 2 \mathrm{M} \mathrm{NH}_{4} \mathrm{H}_{2} \mathrm{PO}_{4}(\mathrm{pH} 4 \cdot 5)$ and acetonitrile (96:4, v/v). A

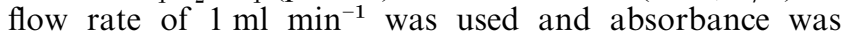


monitored at $270 \mathrm{~nm}$. The calibration curve was obtained from a mixture of four standard nucleosides (Sigma) at a concentration of $0.1 \mathrm{mg} \mathrm{ml}^{-1}$ each in distilled water. After chromatography, the relative concentration of each nucleotide was calculated on the basis of peak areas in the HPLC dilution profile and corrected by coefficients of relative molar absorption, as described previously (Tamaoka \& Komagata, 1984).

\section{RESULTS}

\section{Strain cultivation}

After inoculation of fresh cell culture medium, HEL cells multiplied for approximately $10 \mathrm{~d}$, as observed by using an inverted microscope. Small, coarse and dark inclusions appeared within cells (Fig. 1a). As incubation continued, large, coarse and rounded structures appeared on the cell monolayer and long rope-like
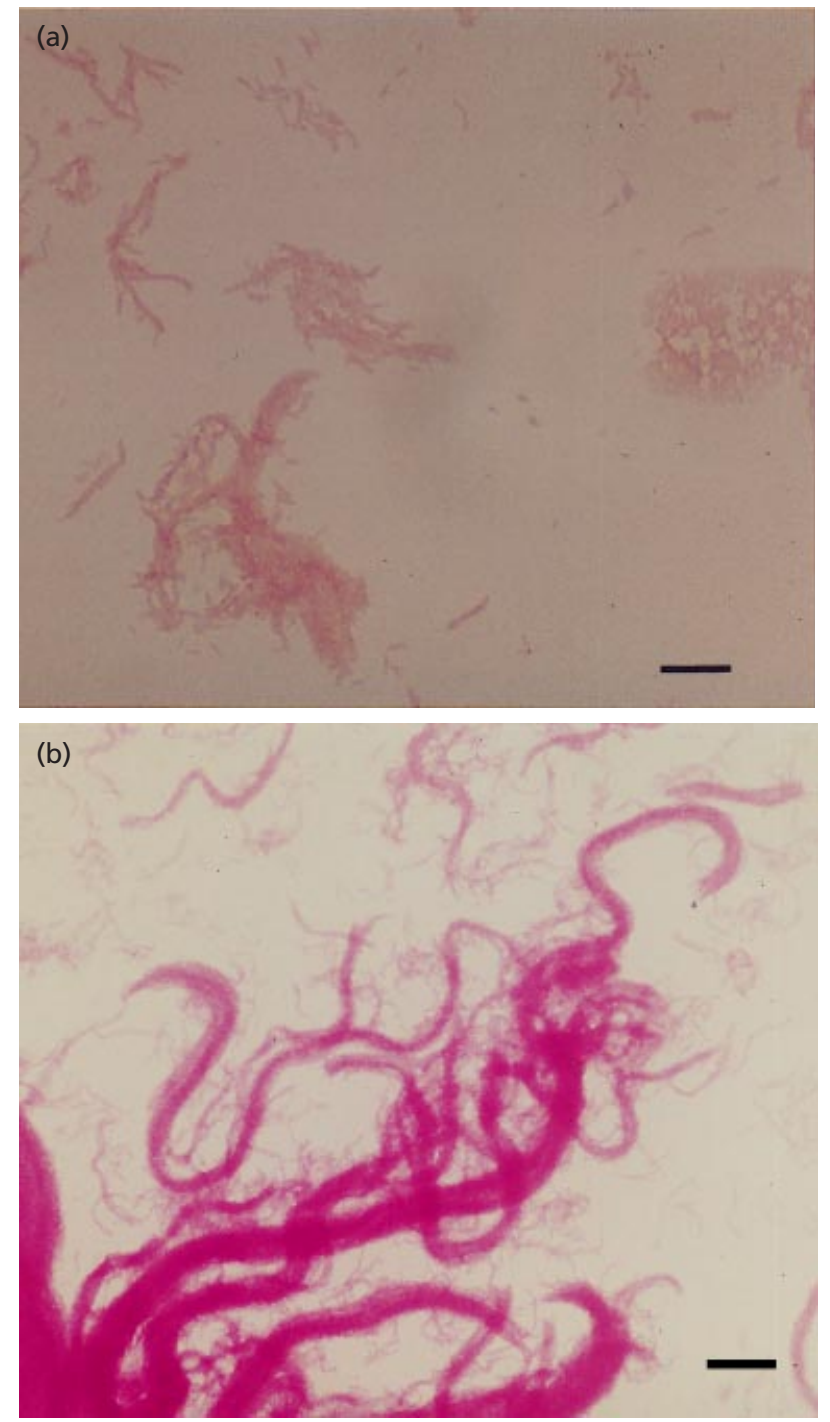

Fig. 2. Staining of extracellular T. whipplei by Gram staining (a) and PAS staining (b). Bars, $15 \mu \mathrm{m}$.

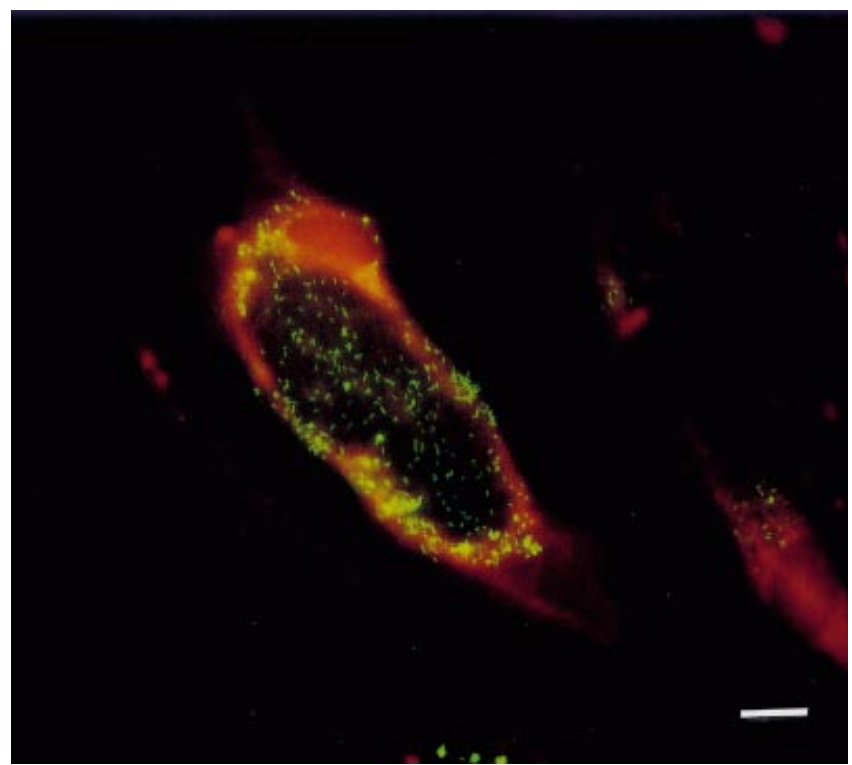

Fig. 3. Immunofluorescence staining of the Whipple's disease bacterium isolate in an infected $\mathrm{HEL}$ cell monolayer in a shell vial, revealed by patient serum. Bar, $6 \mu \mathrm{m}$.

structures appeared in the supernatant (Fig. 1b). As these structures increased in number, the cell population began to decline. Good bacterial growth was obtained on subculture with MRC-5 cells. In HL-60 cells, bacteria were observed mostly as extracellular rods, but these disappeared after three subcultures. Despite incubation for up to 12 weeks, no growth was obtained on any of the axenic media used. The time required to split and passage a cell culture into three subcultures and then to obtain the same degree of infection in the subcultures as observed in the initial culture prior to splitting was about 4 weeks, a period in accordance with the $18 \mathrm{~d}$ doubling time determined previously (Raoult et al., 2000a). To date, we have achieved 29 successful passages of the Whipple's disease bacterium.

\section{Morphological studies}

Stains for optical microscopy. Similar structures were observed with all staining methods. Small, slender bacilli within large vacuoles were observed after cytocentrifugation of cells. Aggregates of bacilli, arranged regularly as long rope-like structures, were observed after cytocentrifugation of supernatants. On Gimenez staining, intracellular rods were poorly stained and appeared as pale-pink structures. Vacuoles appeared bright pink within blue cytoplasm. Aggregates of extracellular bacilli appeared pale blue. On Gram staining, bacterial structures were all poorly stained and always appeared as Gram-negative (Fig. 2a). Bacteria were not visible by Ziehl-Neelsen staining. On May-Grünwald Giemsa, both intracellular bacteria and aggregates were visualized, but intra- 

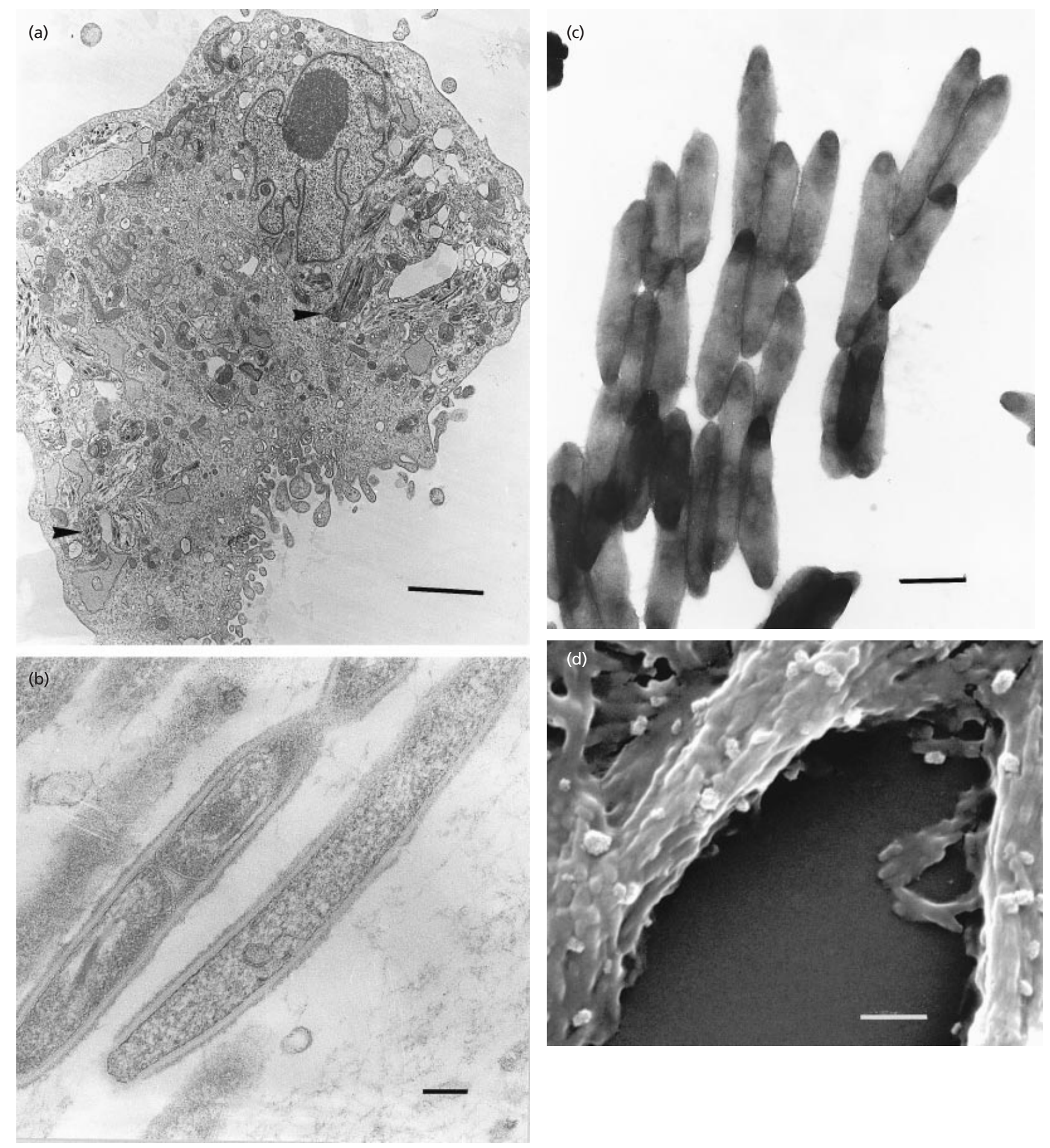

Fig. 4. Electron microscopy of $T$. whipplei cultured in HEL cell monolayers. (a) Transmission electron microscopy of T. whipplei (arrowheads) in HEL cells within vacuoles. Bar, $2 \mu \mathrm{m}$. (b) Transmission electron microscopy of two extracellular T. whipplei cells, of which one is dividing. Bar, $100 \mathrm{~nm}$. (c) Transmission electron microscopy and negative staining of individual extracellular T. whipplei cells. Bar, $500 \mathrm{~nm}$. (d) Scanning electron microscopy of aggregated extracellular T. whipplei cells embedded in an extracellular matrix. Bar, $2 \mu \mathrm{m}$.

cellular bacteria were clustered. Using acridine orange staining, bacteria were visible within cells but were difficult to distinguish from cell components. Aggre- gates of extracellular bacteria appeared bright orange. Better results were obtained with PAS staining, as PAS-positive bacilli appeared more numerous than 
with other stains. Intracellular bacteria were clustered into vacuoles that were clearly visible within the cytoplasm of infected cells. Individual bacteria were also seen within the cytoplasm of infected cells. Thus, cells appeared filled with coarse, PAS-positive conglomerates and short, slender, PAS-positive rods. Most long, slender bacilli were observed extracellularly, usually as aggregates (Fig. 2b).

Immunofluorescence staining. Visualization of bacteria varied according to the source of bacteria used and the antibody used for detection. Patient serum and cytocentrifuged cells revealed few intracellular bacteria on immunofluorescence staining. The same serum on cell monolayer shell-vial cultures allowed good visualization of intracellular bacteria, which appeared brightly fluorescent. The morphology observed with immunofluorescence staining was the same as that observed with PAS staining, with several individual bacteria within vacuoles and large fluorescent vacuoles with no individual bacteria (Fig. 3). Most extracellular bacteria, especially the long rope-like structures, could not be stained. The use of mouse polyclonal antibodies yielded the same results, but allowed detection of bacteria on cytocentrifuged cells. Aggregates in long rope-like structures were again not stained. The success of immunofluorescence staining of cultures was dependent on the age of culture; the presence of large fluorescent vacuoles and non-fluorescent extracellular rods was noted with increasing frequency, the older a culture became.

Electron microscopy. Transmission electron microscopy confirmed that PAS-positive inclusions and immunopositive material corresponded to intact and degenerating bacteria within vacuoles (Fig. 4a). Dividing cells were observed within vacuoles. The cell wall had a specific structure consistent with the previous description of the Whipple's disease bacterium (Silva et al., 1985; Raoult et al., 2000a); the plasma membrane was surrounded by a thin, homogeneous wall and a plasma membrane-like structure, resulting in the typical trilamellar appearance. Long, rope-like structures were aggregates of extracellular bacteria, all orientated in the same direction (Fig. 4b). Dividing cells were observed among the extracellular bacteria. These extracellular bacteria adhered to each other through an extracellular matrix. On negative staining, there was a tendency to aggregate and no flagella were observed (Fig. 4c). On scanning electron microscopy, the bacteria appeared aggregated, orientated in the same direction and embedded in an extracellular matrix (Fig. 4d).

\section{SDS-PAGE analysis and Western blot immunoassay}

SDS-PAGE showed the presence of proteins from 213 to $10 \mathrm{kDa}$, with major protein bands of 213,110 and $85 \mathrm{kDa}$ (Fig. 5). Polyclonal mouse serum recognized several antigens with dominant bands of approximately 40, 110 and $213 \mathrm{kDa}$ and several less intense bands (Fig. 5).

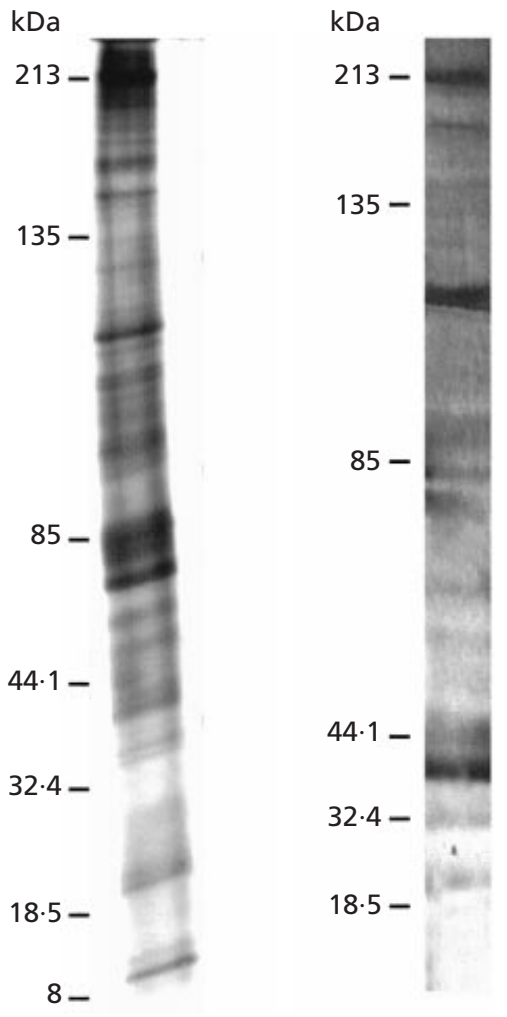

Fig. 5. Silver-stained SDS-PAGE of whole-cell protein preparations of $T$. whipplei (left) and Western blot of $T$. whipplei with mouse polyclonal antiserum (right).

\section{PCR amplification and sequencing of the 16S rRNA gene, ITS region and domain III of 23S rRNA gene}

After amplification and sequencing of the 16S rRNA gene of the isolate, a $1484 \mathrm{bp}$ sequence was compared with DNA sequences accessible in public databases using the program BLAST 2.0. The sequence showed $100 \%$ similarity to two $16 \mathrm{~S}$ rRNA gene sequences of ' $T$. whippelii' available in GenBank (X99636.1 and M874841). The $472 \mathrm{bp}$ sequence derived from the ITS of the isolate showed $100 \%$ similarity to the ITS sequence of ' $T$. whippelii' (GenBank accession no. AF100950) designated by Hinrikson et al. (1999) as genotype 2 . The $225 \mathrm{bp}$ sequence derived from domain III of the $23 \mathrm{~S}$ rDNA sequence from the isolate showed $100 \%$ similarity to the sequence available in GenBank (accession no. AF148136) designated by Hinrikson et al. (2000a) as genotype A. Thus, ' $T$. whippelii' strain Twist-Marseille $^{\mathrm{T}}$ (CNCN I-2202 ${ }^{\mathrm{T}}$ ) corresponds to genotype 2A, as defined by Hinrikson et al. (2000b). The same data were obtained when analysis was performed separately on intracellular or extracellular bacteria.

\section{DNA G + C content}

The DNA $\mathrm{G}+\mathrm{C}$ content was determined to be $59 \cdot 4 \mathrm{~mol} \%$. 


\section{DISCUSSION}

Whipple's disease has long been recognized as a bacterial disease, but the causative agent was not established successfully in vitro until 1999 (Raoult et $a l ., 2000 \mathrm{a})$. The first non-controversial identification of the organism that causes Whipple's disease was provided by Wilson et al. (1991) and was based on partial 16S rDNA gene amplification and sequencing from a single patient. This work has been confirmed and extended with specimens from several patients and controls (Relman et al., 1992). Although no type strain has been available, the provisional name ' $T$. whippelii' is now widely accepted (Relman et al., 1992; Murray \& Schleifer, 1994). A single report of the propagation of ' $T$. whippelii' from cardiac valves was published and two passages of the organism were achieved using human macrophages (Schoedon et al., 1997). However, this isolate no longer exists and was not deposited in a culture collection. We propagated ' $T$. whippelii' using a human fibroblast cell line with no specific culture conditions except for a prolonged incubation period, probably necessary because of the long doubling time (18 d) (Raoult et al., 2000a). Cell lines with short lives, such as human macrophages, cannot therefore be used effectively to propagate the bacterium. Moreover, cells that lack contact inhibition or cannot grow at a slow rate (such as mouse macrophages) are probably also inappropriate.

In cell cultures, Tropheryma whipplei appeared in two forms, an intracellular form located within vacuoles of infected cells and an extracellular form that appeared as massive aggregates of bacteria embedded in an extracellular matrix. The two forms of the bacterium did not have the same staining characteristics. All bacteria were readily visualized by acridine orange or PAS staining. The bacteria always appeared as Gramnegative, despite phylogenetic studies that place $T$. whipplei in the group of Gram-positive bacteria (Maiwald et al., 1996). Intracellular bacteria were stained poorly by Gimenez stain. Immunofluorescence staining of infected cells in shell-vial culture using either mouse polyclonal antibody or serum from a patient with Whipple's endocarditis clearly visualized intracellular bacteria. Cytocentrifuged cells were immunopositive only with mouse polyclonal antiserum. This peculiarity led us to develop an immunofluorescence assay that used labTek slides (Raoult et al., 2000a) rather than our routine assay (La Scola \& Raoult, 1996). Extracellular bacteria were not stained by Gimenez and could not be observed by immunofluorescence. We hypothesize that these differences in staining are due to the extracellular matrix observed around bacteria, which may mask reactive antigens that are exposed when bacteria are degraded by lysosomal enzymes. When harvested separately and inoculated separately on non-infected cells, the two forms of the bacterium (intracellular and extracellular) are able to grow intracellularly, producing long, ropelike structures (data not shown). As no growth was obtained on axenic media in this study or in culture media with lysed eukaryotic cells (Raoult et al., 2000a), the presence of intact cells appears to be necessary for bacterial growth. Although numerous bacteria are observed within cells, the presence of large aggregates of bacteria including dividing cells in the culture supernatant indicates that $T$. whipplei may not be a strictly intracellular bacterium.

The advent of molecular tools such as 16S rDNA amplification and sequencing has led to the identification of bacteria without prior cultivation. Nevertheless, knowledge of a $16 \mathrm{~S}$ rDNA gene sequence alone is not considered a sufficient basis for the formal description of a bacterium. As outlined by several authors (Murray \& Schleifer, 1994; Stackebrandt \& Goebel, 1994), although 16S rDNA sequences may be helpful in separating species, defining new species genetically may require DNA-DNA hybridization. It is well established that different species (as in the genus Bacillus) may have identical 16S rDNA gene sequences (Fox et al., 1992; Ash et al., 1991) and there may also be variation of these sequences within a well-defined species, such as Bartonella henselae (Drancourt et al., 1996). When the 16S rRNA genes of two bacteria are identical, the analysis of alternative, less well-conserved genes may help in assessing the taxonomic juxtaposition of the two strains and therefore provide an indication as to whether or not they belong to the same species. The remarkable diversity in domain III of the 23S rRNA gene found between various bacterial species but not among strains of the same species has led to this DNA fragment being proposed as a suitable alternative to $16 \mathrm{~S}$ rRNA. Indeed, the usefulness of analysis of this domain has previously been demonstrated in defining Actinobacterium taxonomy (Roller et al., 1992). The identity of the 23S rRNA gene sequences of the strain Twist-Marseille ${ }^{\mathrm{T}}$ and those of bacteria detected in other cases of Whipple's disease is therefore a good indicator that all these strains form a single species. Combined analysis of the ITS and the 23S rRNA gene indicates that strain Twist-Marseille ${ }^{\mathrm{T}}$ possesses the $2 \mathrm{~A}$ genotype, as proposed by Hinrikson et al. (2000a, b). However, as this classification is based only on data derived from DNA sequences amplified directly from infected tissues of Whipple's disease patients, determination of its correlation with other, specifically pangenomic typing schemes has not been possible. Clearly, such an undertaking can only be performed when a number of representative strains have been isolated.

That the strain Twist-Marseille ${ }^{\mathrm{T}}$ is indeed a member of the bacterial species implicated in Whipple's disease is further witnessed by the observation that polyclonal antibodies that recognize this strain specifically are also reactive in immunohistochemical visualization of organisms infecting duodenal biopsies taken from patients with typical Whipple's disease (Raoult et al., 2000b). To assist the recording of new putative taxa of prokaryotes based on limited data such as $16 \mathrm{~S}$ rDNA gene sequences, it was proposed that such microorganisms should be given 'Candidatus' status until 
sufficient data become available to give an official name (Murray \& Schleifer, 1994). Following these recommendations, the organism described by Relman et al. (1992) as ' $T$. whippelii' has never been validated. After successful cultivation, including stable subcultures (Raoult et al., 2000a), we provide additional phenotypic and genotypic data that now allow formal description and naming of the new species. To quote Murray \& Schleifer (1994), 'it must be hoped that the candidate names used should be validated, but this cannot be guaranteed, and other names might then be more appropriate'. In order to avoid any confusion that could result from the introduction of a new name, especially for clinicians with patients suffering from Whipple's disease, we propose to retain the name Tropheryma whipplei. We have corrected 'whippelii' to whipplei, as the name Whipple must be correctly Latinized to whippleus and thus the genitive is whipplei.

\section{Description of Tropheryma gen. nov.}

Tropheryma (Tro.phe.ry'ma. Gr. n. trophe nourishment; Gr. n. eryma barrier; N.L. fem. n. Tropheryma barrier to nourishment, so named because it causes malabsorption).

The type species is Tropheryma whipplei. The genus and species descriptions are combined below until further species are described.

\section{Description of Tropheryma whipplei sp. nov.}

Tropheryma whipplei (whipp'le.i. N.L. gen. n. whipplei of Whipple, after George Whipple, who described the first patient with the clinical syndrome that is today known as Whipple's disease).

Formerly named 'Tropheryma whippelii'. Short rods, $0 \cdot 25-0.3 \mu \mathrm{m}$ in diameter and $0 \cdot 8-1 \cdot 7 \mu \mathrm{m}$ long, sometimes longer when cell division is impaired. Nonmotile. Flagella do not occur. The plasma membrane is surrounded by a thin homogeneous wall and by a plasma membrane-like structure, resulting in a trilamellar appearance of the cell wall under electron microscopy. Appear Gram-negative. Ziehl-negative. Retain basic fuchsin when stained by the method of Gimenez when intracellular. Well stained by PAS staining. Although we have shown that the bacterium can be observed extracellularly, it has not been cultivated in the absence of host cells. Grows well in or associated with HEL and MRC-5 cells in minimal essential medium with $10 \%$ foetal calf serum and $2 \mathrm{mM}$ L-glutamine when incubated at $37{ }^{\circ} \mathrm{C}$ in a $5 \%$ $\mathrm{CO}_{2}$ atmosphere. May be observed in an intracellular or extracellular location. When extracellular, has a tendency to aggregate in masses of bacteria embedded in an extracellular matrix, with the appearance of long, rope-like structures. Doubling time has been estimated to be $18 \mathrm{~d}$. Well preserved by rapid freezing and storage at $-80^{\circ} \mathrm{C}$. On SDS-PAGE, proteins of 213 to $10 \mathrm{kDa}$ are detected, with major bands of 213 and $85 \mathrm{kDa}$. Sequence of the $16 \mathrm{~S}$ rDNA gene places it in the class Actinomycetes and sequences of the $16 \mathrm{~S}-23 \mathrm{~S}$
rDNA ITS and domain III of the 23S rDNA identify the strain as genotype $2 \mathrm{~A}$. The DNA G $+\mathrm{C}$ content of strain Twist-Marseille ${ }^{\mathrm{T}}$ is $59 \cdot 4 \mathrm{~mol} \%$. Opportunistic pathogen for humans. Responsible for Whipple's disease, a systemic infection with symptoms of fever, weight loss, diarrhoea, polyadenopathy and polyarthritis. Occasionally responsible for cardiac manifestations such as myocarditis, pericarditis and endocarditis or central nervous system involvement that may include dementia, lethargy and neurological deficits or ocular diseases such as uveitis.

The type strain is Twist-Marseille ${ }^{\mathrm{T}}$ (=CNCM I$2202^{\mathrm{T}}$ ), isolated from the aortic valve of a patient with endocarditis. This strain has been deposited in the Collection Nationale de Cultures de Micro-organismes (CNCM, Institut Pasteur, Paris, France) and the Collection de l'Unité des Rickettsies (WHO Collaborative Center for Rickettsial Reference and Research, Marseilles, France), and is available upon request from the authors or from the Institut National de la Propriété Industrielle (Paris, France).

\section{ACKNOWLEDGEMENTS}

The authors are indebted to R. J. Birtles for reviewing the manuscript, M. Enea, M. L. Birg and G. Vestris for production of the strain, C. Cataldo and J. P. Chauvin for scanning electron microscopy and $\mathrm{H}$. Trüper for etymological help in correctly renaming the micro-organism.

\section{REFERENCES}

Ash, C., Farrow, J. A. E., Dorsch, M., Stackebrandt, E. \& Collins, M. D. (1991). Comparative analysis of Bacillus anthracis, $\mathrm{Ba}$ cillus cereus, and related species on the basis of reverse transcriptase sequencing of 16S rRNA. Int J Syst Bacteriol 41, 343-346.

Ausubel, F. M., Brent, R., Kingston, R. E., Moore, D. D., Seidman, J. G., Smith, J. A. \& Struhl, K. (editors) (1995). Current Protocols in Molecular Biology, pp. 2.2.1-2.4.5. New York: Wiley.

Black-Schaffer, B. (1949). The tinctoral demonstration of a glycoprotein in Whipple's disease. Proc Soc Exp Biol 72, 225-227.

Chapin, K. (1995). Clinical microscopy. In Manual of Clinical Microbiology, pp. 33-51. Edited by P. R. Murray, E. J. Baron, M. A. Pfaller, F. C. Tenover \& R. H. Yolken. Washington, DC: American Society for Microbiology.

Drancourt, M., Birtles, R. J., Chaumentin, G., Vandenesch, F., Etienne, J. \& Raoult, D. (1996). New serotype of Bartonella henselae in endocarditis and cat-scratch disease. Lancet $\mathbf{3 4 7}$, 441-443.

Dutly, F., Hinrikson, H. P., Seidel, T., Morgenegg, S., Altwegg, M. \& Bauerfeind, P. (2000). Tropheryma whippelii DNA in saliva of patients without Whipple's disease. Infection 28, 219-222.

Ehrbar, H. U., Bauerfeind, P., Dutly, F., Koelz, H. R. \& Altwegg, M. (1999). PCR-positive tests for Tropheryma whippelii in patients without Whipple's disease. Lancet 353, 2214.

Fox, G. E., Wisotzkey, J. D. \& Jurtshuk, P., Jr (1992). How close is close: 16S rRNA sequence identity may not be sufficient to guarantee species identity. Int J Syst Bacteriol 42, 166-170.

Gimenez, D. F. (1964). Staining rickettsiae in yolk-sac cultures. Stain Technol 39, 135-140. 
Hinrikson, H. P., Dutly, F., Nair, S. \& Altwegg, M. (1999). Detection of three different types of 'Tropheryma whippelii' directly from clinical specimens by sequencing, single-strand conformation polymorphism (SSCP) analysis and type-specific PCR of their $16 \mathrm{~S}-23 \mathrm{~S}$ ribosomal intergenic spacer region. Int $J$ Syst Bacteriol 49, 1701-1706.

Hinrikson, H. P., Dutly, F. \& Altwegg, M. (2000a). Analysis of the actinobacterial insertion in domain III of the 23S rRNA gene of uncultured variants of the bacterium associated with Whipple's disease using broad-range and 'Tropheryma whippelii'-specific PCR. Int J Syst Evol Microbiol 50, 1007-1011.

Hinrikson, H. P., Dutly, F. \& Altwegg, M. (2000b). Evaluation of a specific nested PCR targeting domain III of the 23S rRNA gene of 'Tropheryma whippelii' and proposal of a classification system for its molecular variants. J Clin Microbiol 38, 595-599.

Laemmli, U. K. (1970). Cleavage of structural proteins during the assembly of the head of bacteriophage T4. Nature 227, 680-685.

La Scola, B. \& Raoult, D. (1996). Serological cross-reactions between Bartonella quintana, Bartonella henselae, and Coxiella burnetii. J Clin Microbiol 34, 2270-2274.

La Scola, B., Michel, G. \& Raoult, D. (1997). Use of amplification and sequencing of the $16 \mathrm{~S}$ rRNA gene to diagnose Mycoplasma pneumoniae osteomyelitis in a patient with hypogammaglobulinemia. Clin Infect Dis 24, 1161-1163.

La Scola, B., Birtles, R. J., Mallet, M. N. \& Raoult, D. (1998). Massilia timonae gen. nov., sp. nov., isolated from blood of an immunocompromised patient with cerebellar lesions. $J$ Clin Microbiol 36, 2847-2852.

Maiwald, M., Ditton, H.-J., von Herbay, A., Rainey, F. A. \& Stackebrandt, E. (1996). Reassessment of the phylogenetic position of the bacterium associated with Whipple's disease and determination of the $16 \mathrm{~S}-23 \mathrm{~S}$ ribosomal intergenic spacer sequence. Int J Syst Bacteriol 46, 1078-1082.

Maizel, H., Ruffin, J. M. \& Dobbins, W. O., III (1970). Whipple's disease: a review of 19 patients from one hospital and a review of the literature since 1950. Medicine 49, 175-205.

Murray, R. G. E. \& Schleifer, K. H. (1994). Taxonomic notes: a proposal for recording the properties of putative taxa of procaryotes. Int J Syst Bacteriol 44, 174-176.

Nesterenko, M. V., Tilley, M. \& Upton, S. J. (1994). A simple modification of Blum's silver strain method allows for 30 minute detection of proteins in polyacrylamide gels. $J$ Biochem Biophys Methods 28, 239-242.

Ramzan, N. N., Loftus, E., Jr, Burgart, L. J., Rooney, M., Batts, K. P., Wiesner, R. H., Fredricks, D. N., Relman, D. A. \& Persing, D. H. (1997). Diagnosis and monitoring of Whipple disease by polymerase chain reaction. Ann Intern Med 126, 520-527.

Raoult, D., Birg, M. L., La Scola, B. \& 8 other authors (2000a). Cultivation of the bacillus of Whipple's disease. New Engl $J$ Med 342, 620-625.

Raoult, D., La Scola, B., Lepidi, H., Fournier, P. E. (2000b) Culture and immunological detection of Tropheryma whipplei from the duodenal biopsy of a patient with Whipple's disease. The 40th Interscience Conference on Antimicrobial Agents and Chemotherapy, Toronto, Canada. Abstract L-2.

Ratliff, N. B., McMahon, J. T., Naab, T. J. \& Cosgrove, D. M. (1984). Whipple's disease in the porcine leaflets of a CarpentierEdwards prosthetic mitral valve. $N$ Engl J Med 311, 902-903.

Relman, D. A. (1997). The Whipple bacillus lives (ex vivo)! $J$ Infect Dis 176, 752-754.

Relman, D. A., Schmidt, T. M., MacDermott, R. P. \& Falkow, S. (1992). Identification of the uncultured bacillus of Whipple's disease. $N$ Engl J Med 327, 293-301.

Roller, C., Ludwig, W. \& Schleifer, K. H. (1992). Gram-positive bacteria with a high DNA $\mathrm{G}+\mathrm{C}$ content are characterized by a common insertion within their $23 \mathrm{~S}$ rRNA genes. $J$ Gen Microbiol 138, 1167-1175.

Schoedon, G., Goldenberger, D., Forrer, R., Gunz, A., Dutly, F., Hochli, M., Altwegg, M. \& Schaffner, A. (1997). Deactivation of macrophages with interleukin-4 is the key to the isolation of Tropheryma whippelii. J Infect Dis 176, 672-677.

Silva, M. T., Macedo, P. M. \& Moura Nunes, J. F. (1985). Ultrastructure of bacilli and the bacillary origin of the macrophagic inclusions in Whipple's disease. $J$ Gen Microbiol 131, 1001-1013.

Stackebrandt, E. \& Goebel, B. M. (1994). Taxonomic note: a place for DNA-DNA reassociation and $16 \mathrm{~S}$ rRNA sequence analysis in the present species definition in bacteriology. Int $J$ Syst Bacteriol 44, 846-849.

Street, S., Donoghue, H. D. \& Neild, G. H. (1999). Tropheryma whippelii DNA in saliva of healthy people. Lancet 354, 1178-1179.

Tamaoka, J. \& Komagata, K. (1984). Determination of DNA base composition by reversed-phase high-performance liquid chromatography. FEMS Microbiol Lett 25, 125-128.

Vital-Durand, D., Lecomte, C., Cathebras, P., Rousset, H. \& Godeau, P. (1997). Whipple disease. Clinical review of 52 cases. Medicine 76, 170-184.

Weisburg, W. G., Barns, S. M., Pelletier, D. A. \& Lane, D. J. (1991). $16 \mathrm{~S}$ ribosomal DNA amplification for phylogenetic study. $J$ Bacteriol 173, 697-703.

Whipple, G. H. (1907). A hitherto undescribed disease characterized anatomically by deposits of fat and fatty acids in the intestinal and mesenteric lymphatic tissues. Bull Johns Hopkins Hosp 18, 382-393.

Wilson, K. H., Blitchington, R., Frothingham, R. \& Wilson, J. A. (1991). Phylogeny of the Whipple's-disease-associated bacterium. Lancet 338, 474-475.

Woods, G. L. \& Walker, D. H. (1996). Detection of infection or infectious agents by use of cytologic and histologic stains. Clin Microbiol Rev 9, 382-404.

Yardley, J. \& Hendrix, T. (1961). Combined electron and light microscopy in Whipple's disease. Bull Johns Hopkins Hosp 109, 80-98. 